\title{
Distribution of Glutathione S-Transferase Omega Gene Polymorphism with Different Stages of HBV Infection Including Hepatocellular Carcinoma in the Egyptian Population
}

\author{
Nadia Z Shaban ${ }^{1 *}$, Halima H Salem ${ }^{2}$, Mohamed A Elsadany ${ }^{1}$, Bahy A Ali ${ }^{2}$, Ehab \\ M Hassona $^{3}$, Fayed AK Mogahed ${ }^{2}$
}

\begin{abstract}
Background: Infection with hepatitis B virus (HBV) is a major global public health problem, with a wide spectrum of clinical manifestations. Human cytosolic glutathione-S-transferases (GSTs) include several classes such as alpha $(\mathrm{A})$, mu $(\mathrm{M})$, pi $(\mathrm{P})$, sigma $(\mathrm{S})$, zeta $(\mathrm{Z})$, omega $(\mathrm{O})$ and theta $(\mathrm{T})$. The present study aimed to investigate the role of GST omega genes (GSTO1 and GSTO2) in different groups of patients infected with HBV. Materials and Methods: HBV groups were classified according to clinical history, serological tests and histological analysis into normal carriers (N), acute (A), chronic (CH), cirrhosis (CI) and hepatocellular carcinoma (HCC) cases. The study focused on determination of the genotypes of GST omega genes (GSTO1 and GSTO2) and GST activity and liver function tests. Results: The results showed that GSTO1 (A/A) was decreased in N, A, CH, CI and HCC groups compared to the C-group, while, GSTO1 (C/A) and GSTO1(C/C) genotypes were increased significantly in N, A, CH, CI and HCC groups. GSTO2 (A/A) was decreased in all studied groups as compared to the C-group but GSTO2(A/G) and GSTO2(G/G) genotypes were increased significantly. In addition, GST activities, albumin and TP levels were decreased in all studied groups compared to the C-group, while the activities of transaminases were increased to differing degrees. Conclusions: The results indicate that GSTO genetic polymorphisms may be considered as biomarkers for determining and predicting the progression of HBV infection.
\end{abstract}

Keywords: HBV - infection - cirrhosis - HCC - GST - omega genes - genetic polymorphisms

Asian Pac J Cancer Prev, 17 (4), 2145-2150

\section{Introduction}

Glutathione S-transferases (GSTs, EC 2.5.1.18) are a family of enzymes that play an important role in detoxification by catalyzing the conjugation of many hydrophobic and electrophilic compounds with reduced glutathione (Shaban et al., 2003, 2013, 2014 a \& b). In general, GSTs protect cellular macromolecules from damage caused by several xenobiotics (Shaban et al., 2013). GSTs are divided into two distinct super-family members: the membrane-bound microsomal and cytosolic family members.

Microsomal GSTs are structurally distinct from the cytosolic in that they are homo- and heterotrimerize rather than dimerize to form a single active site. Microsomal GSTs play a key role in the endogenous metabolism of leukotrienes and prostaglandins. The cytosolic GSTs are categorized into several classes according to their genetic and biochemical properties such as alpha (A), mu (M), omega $(\mathrm{O})$, pi $(\mathrm{P})$, sigma $(\mathrm{S})$, theta $(\mathrm{T})$, and zeta $(\mathrm{Z})$ families (Strange et al., 2001, Li et al., 2003, Shaban et al., 2014c \& d).

The GST omega class (GSTO) contains two expressed genes GSTO1 $(12.5 \mathrm{~kb})$ and GSTO2 $(24.5 \mathrm{~kb})$ beside a pseudo gene GSTO3p. GSTO1 and GSTO2 are 12.5 and $24.5 \mathrm{~kb}$, respectively, and lie $7.5 \mathrm{~kb}$ on chromosome 10q25.1 (Polimantia et al., 2011). Members of this family do not display activity with "classical" GST substrates such as 1-chloro-2,4-dinitrobenzene, dichloromethane, or ethacrynic acid, but they do exhibit several enzymatic characteristics of glutaredoxins (Board et al., 2000, Whitbread et al., 2003). Although most GSTs have a serine or tyrosine residue at the active site, the GSTOs have cysteine, as well as a 19-amino acid extension at the $\mathrm{N}$ terminus that is not present in other cytosolic GSTs (Board et al., 2000). The genes encoding GSTO1 and GSTO2 map to chromosome 10 and are separated by approximately $1.5 \mathrm{~kb}$ (Whitbread et al., 2003). Both GSTO1 and

${ }^{1}$ Biochemistry Department, Faculty of Science, ${ }^{3}$ Internal Medicine Department, Faculty of Medicine, Alexandria University, ${ }^{2}$ Nucleic Acid Research Department, Genetic Engineering and Biotechnology Research Institute, City of Scientific Research and Technological Applications, Alexandria, Egypt*For correspondence: nshaban2001@yahoo.co.uk 
GSTO2 catalyze the reduction of monomethyl arsenate from an oxidation state of $+\mathrm{V}$ to + III (Schmuck et al., 2005, Mukherjee et al., 2006). GSTO1 and GSTO2 have been identified in many organisms, including humans, and have poor activity with common GST substrates (Whitbread et al., 2003, Pongstaporn et al., 2008). GSTO1 plays a role in apoptosis and is a potential reservoir of intracellular glutathione (GSH), which protects against cellular oxidative stress (Ada et al., 2013). The gene polymorphisms of GSTO1 have been associated with the risk of human cancers, such as hepatocellular carcinoma, cholangiocarcinoma, and breast cancer (Marahatta et al., 2006). While GSTO2 polymorphism has been reported in ovarian cancer (Pongstaporn et al., 2006). Genetic studies of common complex diseases have focused on identifying risk genes as targets for developing new treatments and improved diagnoses. This approach led to the identification of several genes (Li et al., 2003). Genetic variation in GSTs has been reported to represent a risk factor for a variety of cancers (Strange et al., 2001).

Hepatitis B virus, abbreviated HBV, is species of the genus Orthohepadnavirus, which is likewise a part of the Hepadnaviridae family of viruses. HBV causes hepatitis B (Hassan et al., 2008) and leads to cirrhosis and hepatocellular carcinoma (Chisari and Ferrari, 1995, Hassan et al., 2008). The prevalence of HBV infection varies widely among different parts of the world and this variability is due to the primary cause of disease and inter-individual differences in target proteins and drug metabolism (Chisari and Ferrari, 1995). Progress of HBV infection may be affected by host genetic susceptibility (Wang, 2003). However, hepatitis is a systemic infectious process, and HBV virus may travel through the bloodstream and be deposited in non liver tissue- for example, kidney, skin, and vessel walls (Locarnini and Shaw, 2004). So it has been suggested that it may increase the risk of pancreatic cancer (Hassan et al., 2008).

Previous studies demonstrated that GSTs genetic polymorphism may be considered as an accurate biomarker for investigation, prediction and progression of HBV infection in Egypt (Polimantia et al., 2011, Shaban et al., $2014 \mathrm{~d}$ )). Till now, there are no studies evaluating how much of known GSTO polymorphism can contribute to the development of HBV cirrhosis in human. In this study, the incidence of GSTO1 and GSTO2 polymorphism in patients with different stages of HBV infection was analyzed to investigate the role of host genetic factors in HBV infection.

\section{Materials and Methods}

\section{Chemicals and kits}

Kits for albumin, AST and ALT kits were obtained from Borax diagnostic, England, Prodia international, Germany and Crest Biosystem, India, respectively. Kits for bilirubin and total protein were obtained from Diamond, Egypt and Spinreact, Spain, respectively. GST assay kit was obtained from Cornel lab, USA; protienase K was obtained from Amersco, USA; primers and Polymerase chain reaction (PCR) kits was obtained from Microgen,
South Korea and Promega, USA, respectively. Agarose was obtained from Bioshop, Germany; Cac8I and MboI restriction enzymes were obtained from New England Biolab, England . DNA loading buffer and ladders were obtained from Promega, USA. Phenol equilibrated and chloroform was obtained from Acrosorganic, USA and Applichem, Germany, respectively.

\section{Patients and Control:}

Different blood samples were collected from different hospitals, medical laboratories and hepatologist clinics in Egypt according to the rules of scientific research ethics under supervision of Prof. Dr. Ehab Hassona (Internal Medicine Department, Faculty of Medicine, Alexandria University, Alexandria, Egypt). Complete demographic data and full clinical history were recorded. Blood samples of 470 persons (160 females and 310 males) which included 150 healthy persons (control group) and 320 patients: The age of studied cases was $(43 \pm 13)$ years. The patients were classified into five groups according to clinical history, serological tests and histological analysis as follow: 67 normal HBV carriers, 53 acute patients, 78 chronic patients, 62 cirrhotic patients, and 60 hepatocellular carcinoma patients.

Sample preparation: Five $\mathrm{ml}$ of blood from each person were collected, left at room temperature for $10 \mathrm{~min}$ and then centrifuged at $8000 \mathrm{rpm}$ for $5 \mathrm{~min}$ at $4{ }^{\circ} \mathrm{C}$. All serum samples were stored at $-80{ }^{\circ} \mathrm{C}$.

\section{Molecular Assays:}

DNA extraction from serum: Genomic DNA was extracted from different serum samples manually (Miller et al., 1988). Briefly, $0.2 \mathrm{ml}$ of serum were added to 0.6 $\mathrm{ml}$ of lysis buffer (10 mM Tris- $\mathrm{HCl}, \mathrm{pH} 8) \mathrm{H}_{2} \mathrm{O} 400 \mathrm{mM}$ $\mathrm{NaCl}, 2 \mathrm{mM} \mathrm{Na}{ }_{2}$ EDTA, $\mathrm{pH}$ 8.2) and mixed well. Then $0.2 \mathrm{ml}$ of $10 \%$ SDS and $20 \mu \mathrm{l}$ of proteinase $\mathrm{K}$ solution were added and incubated for 2 hours at $37^{\circ} \mathrm{C}$. Then 0.6 $\mathrm{ml}$ of $6 \mathrm{M} \mathrm{NaCl}$ were added, mixed well and centrifuged at $12000 \mathrm{rpm}$ for 20 minutes at $4{ }^{\circ} \mathrm{C}$. Then $0.5 \mathrm{ml}$ of the supernatant was added to $1.0 \mathrm{ml}$ of absolute ethanol, mixed well and incubated for 12 hours at $-20^{\circ} \mathrm{C}$, then centrifuged at $12000 \mathrm{rpm}$ for 20 minutes at $4{ }^{\circ} \mathrm{C}$ and the supernatant was discarded. The pellets were washed twice with 0.5 $\mathrm{ml}$ of $70 \%$ ethanol and dried in laminar. The dried pellets were dissolved in $70 \mu \mathrm{l}$ of TE buffer (10 mM EDTA, 10 $\mathrm{mM}$ Tris- $\mathrm{HCl})$. The concentration and the purity of DNA in $10 \mu 1$ samples was measured using spectrophotometer (A 260 / A 280) (William, 1997).

Primers: Specific primers were designed to detect GSTO1 and GSTO2. The primers sequences, annealing temperatures, annealing times and PCR product sizes were shown in Table 1 (Pongstaporn and Pakakasam 2009).

Detection of GSTO1: Specific PCR was used to detect GSTO1. In brief, $2.5 \mu \mathrm{l}$ (50 ng) of isolated DNA was added to $2.5 \mu \mathrm{l}$ of $2 \mathrm{mmol} / \mathrm{L}$ dNTPs, $5 \mu \mathrm{l}$ of $10 \mathrm{X}$ PCR buffer containing $1.5 \mathrm{mmol} / \mathrm{L} \mathrm{MgCl}_{2}, 2 \mu \mathrm{l}(20 \mathrm{pmol})$ of GSTO1 primers , $0.5 \mu \mathrm{l}(5 \mathrm{u} / \mu \mathrm{l})$ of Taq DNA polymerase and 10.5 $\mu \mathrm{l}$ deionized distilled $\mathrm{H}_{2} \mathrm{O}\left(\right.$ d. $\left.\mathrm{d} \mathrm{H}_{2} \mathrm{O}\right)$. PCR program was $1 \mathrm{~min}$ at $94^{\circ} \mathrm{C}$ followed by 35 cycles of $\left(1 \mathrm{~min}\right.$ at $94^{\circ} \mathrm{C}$, $1 \mathrm{~min}$ at $61^{\circ} \mathrm{C}$, and $1 \mathrm{~min}$ at $72^{\circ} \mathrm{C}$, and $10 \mathrm{~min}$ at $72^{\circ} \mathrm{C}$ ) .The PCR products were analyzed electrophoretically on 
a $2 \%$ agarose gel containing $0.5 \mu \mathrm{g} / \mathrm{ml}$ ethidium bromide with $1.5 \mathrm{~kb}$ DNA ladder. Five $\mu \mathrm{l}$ of the PCR product was digested with $1.5 \mu \mathrm{l}(1 \mathrm{U} / \mu \mathrm{l})$ of Cac8I, $2.5 \mu \mathrm{l}$ of $10 \mathrm{X}$ reaction buffer and $11 \mu \mathrm{l}$ of d.d $\mathrm{H}_{2} \mathrm{O}$, mixed well and incubated at $37^{\circ} \mathrm{C}$ for 18 hours. The digested fragments were analyzed electrophoretically on $3 \%$ agarose gel containing $0.5 \mu \mathrm{g} / \mathrm{ml}$ ethidium bromide with $1.5 \mathrm{~kb}$ DNA ladder (Pongstaporn and Pakakasam 2009).

Detection of GSTO2: It was detected as described before in GSTO1 gene. Five $\mu 1$ of the PCR product was digested with $1.5 \mu \mathrm{l}(1 \mathrm{U} / \mu \mathrm{l})$ of $\mathrm{MboI}$ as described before in the condition of GSTO1gene (Pongstaporn and Pakakasam 2009).

HBV DNA titer values: HBV DNA titer values of the different stages of HBV infection were determined by Real Time PCR (Roch Diagnostic, USA) (Chu et al., 2002).

\section{Biochemical Assays}

GST (EC 2.5.1.18) activity: It was determined using kit (Habig et al., 1974). The specific activity is defined as U/L.

Liver Function Tests: Total protein (TP), albumin, total bilirubin (TB), transaminases [aspartate tranaminase (AST) and alanine transaminase (ALT)], were determined using specific kits (Danil et al., 1999).

Statistical analysis: Frequencies and associations between specific genotypes, GST activities and liver function tests were examined by use of logistic regression to calculate the mean $\pm \mathrm{SD}, \mathrm{P}$. values, $\mathrm{R}$ square and upper and lower values of $95 \%$ confidence intervals (CI). SPSS for Windows (version 11.0) statistical package was used for all statistical comparisons. A value of $\mathrm{P}<0.05$ was considered significant.

\section{Results}

Agarose gel electrophoresis: The electrophoresis of GSTO1 gene, lane 2, represents negative sample. The molecular sizes (MS) of GSTO1 PCR products were 254 bp as compared to DNA marker (lane M) as shown in (Figure1A). Electrophoresis of GSTO2 gene, lane 6 represents negative sample. The molecular sizes (MS) of GSTO2 PCR products were 185 bp as compared to DNA marker (lane M) as shown in (Figure1B). For GSTO1 genotypes, the $\mathrm{MS}$ of $\mathrm{C} / \mathrm{C}$ wild type homozygote was 186 and $68 \mathrm{bp}$ fragments, the MS of A/A polymorphic homozygote exhibited $254 \mathrm{bp}$ respectively, (Figure 2). For GSTO2 genotypes, the MS of G/A heterozygote exhibited 185, 122, and $63 \mathrm{bp}$ fragments, the MS of A/A wild type homozygote was $185 \mathrm{bp}$ fragment, the MS of $\mathrm{G} / \mathrm{G}$ polymorphic homozygote presented the expected 122 and 63 bp fragments (Figure 3A \& 3B, respectively).

GST activity: GST activities were decreased significantly in N, A, CH, CI and HCC groups by about $40.1 \%, 52.9 \%, 57 \%, 54.3 \%$ and $65.8 \%$, respectively as compared to the control group (Table 2).

Liver Function Tests: Serum (TP) and albumin levels were decreased significantly in $\mathrm{N}, \mathrm{A}, \mathrm{CH}, \mathrm{CI}$ and $\mathrm{HCC}$ groups by about $(35.4 \%, 51.3 \%, 48.2 \%, 49.2 \%$ and $54.8 \%$, respectively, for TP and $(39.6 \%, 51.3 \%, 62 \%, 62.8 \%$ and $69.6 \%$, respectively, for albumin, (Table 2) as compared to the control group. Serum AST and ALT activities in N,
Distribution of GST Omega Genes with HBV Infection Stages

A, CH, CI and HCC groups were increased significantly by about $(114.8 \%, 169.8 \%, 128.9 \%, 261 \%$ and $97, \%$ respectively, for AST) and $(98.9 \%, 288.6 \%, 24.7 \%$, $85.4 \%$ and $341.9 \%$, respectively, for ALT) as compared to the control group. Also serum TB levels were increased significantly in N, A, CH, CI and HCC groups by about $393.9 \%, 615.6 \%, 520.4 \%, 780.7 \%$, 906\%, respectively, as compared to the control group (Table 2).

\section{Genetic polymorphism of GSTO genes}

GSTO1: GSTO1 (A/A) was decreased significantly in $\mathrm{N}, \mathrm{A}, \mathrm{CH}, \mathrm{CI}$ and $\mathrm{HCC}$ groups by about $83.3 \%, 72.2 \%$, $88.9 \%, 77.7 \%$ and $83.3 \%$ respectively, however, GSTO1 (CA) and GSTO1 (C/C) genotypes were increased significantly \{ (by about 77.7\%, 122.2\%,107.3\%, 62.9\% and $48.1 \%$ respectively, for GSTO1 (C/A)and (by about $185.7 \%, 90.4 \%, 166.6 \%, 185.7 \%$ and $223.7 \%$ respectively,

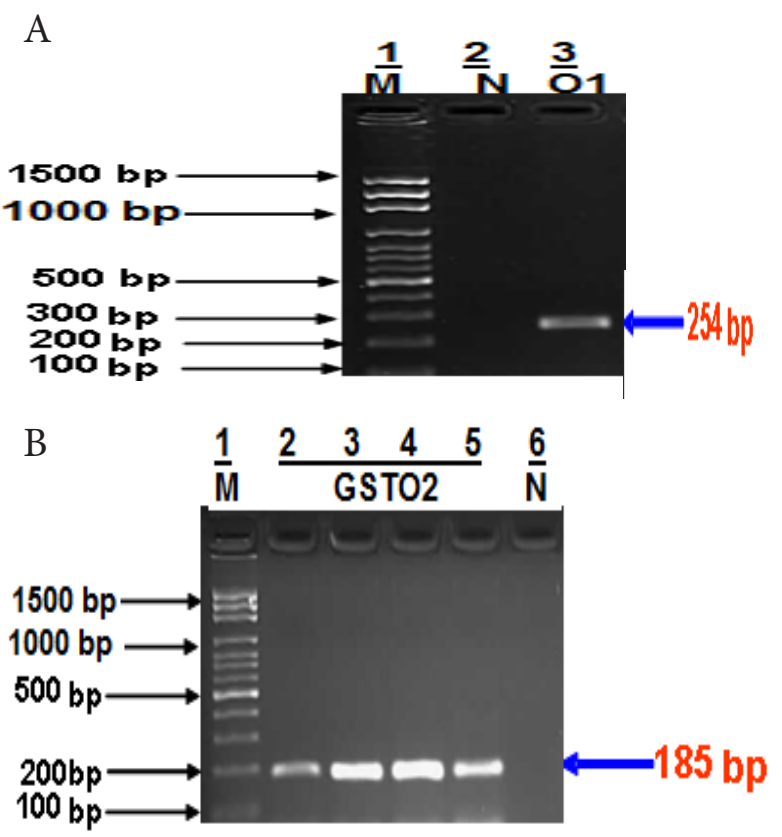

Figure 1. Agarose Gel Electrophoresis Findings. (A) of GSTO1 PCR product. Lane 1 (M): $1.5 \mathrm{~kb}$ DNA marker, Lane 2: negative control and Lane 3: $254 \mathrm{bp}$ PCR fragment amplified from GSTO1 gene. B): Agarose gel electrophoresis of GSTO2 PCR products. Lane $1(\mathrm{M}): 1.5 \mathrm{~kb}$ DNA marker, Lanes 2, 3, 4\&5: 185 bp PCR fragments amplified from GSTO2 gene and Lane 6: negative control

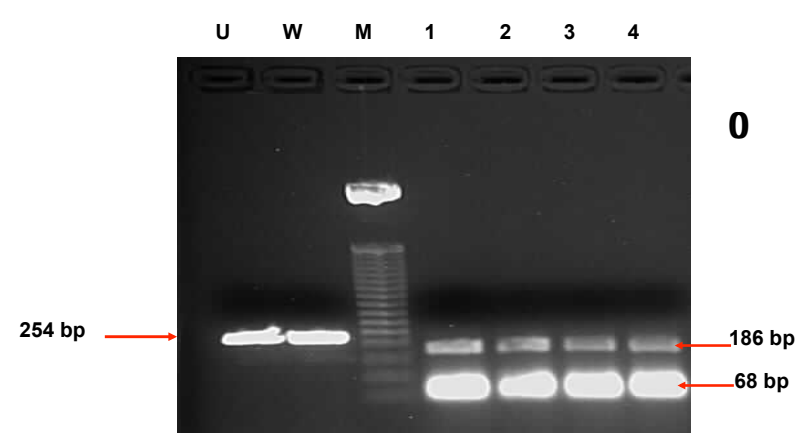

Figure 2. Agarose Gel Electrophoresis Findings for GSTO1 PCR-RFLP Products. Lane U, uncut band (254 bp).lane W, A/A polymorphic homozygous (254 bp).lane M ,50 bp DNA ladder. Lanes 1-4 , C/C wild type (186 bp and 68 bp) 


\begin{tabular}{lccc}
\hline Primers & Primer Sequence & Ta( C ) / T (s) & PCR product size (bp) \\
\hline GSTO1F & GAA CTT GAT GCA CCC TTG GT & $61 / 60$ & 254 \\
GSTO1R & TGA TAG CTA GGA ATA ATT AC & & \\
GSTO2F & AGG CAG AAC AGG AAC TGG AA & $61 / 60$ & 185 \\
GSTO2R & GAG GGA CCC CTT TTT GTA CC & & \\
\hline
\end{tabular}

Ta:annealing temperature; T(s):Time per seconds; bp:base pairs

Table 2. GST Activities and Liver Function Tests in Different Studied Groups

\begin{tabular}{lcccccc}
\hline Studied groups & $\mathrm{GST}(\mathrm{U} / \mathrm{L})$ & $\mathrm{TP}(\mathrm{mg} / \mathrm{dl})$ & $\mathrm{TB}(\mathrm{mg} / \mathrm{dl})$ & $\mathrm{AST}(\mathrm{U} / \mathrm{L})$ & ALT(U/L) & ALB(mg/dl) \\
\hline control & 11.6 & 7.55 & 0.83 & 11.88 & 13.65 & 4.77 \\
Normal & 6.94 & 4.87 & 4.1 & 25.53 & 27.16 & 2.88 \\
Acute & 5.46 & 3.67 & 5.94 & 32.06 & 53.05 & 2.32 \\
Chronic & 4.98 & 3.91 & 5.15 & 27.2 & 17.03 & 1.81 \\
Cirrhosis & 5.3 & 3.83 & 7.31 & 42.9 & 25.32 & 1.77 \\
HCC & 3.96 & 3.41 & 8.35 & 23.41 & 60.33 & 1.45 \\
P.value & 0.004 & 0.003 & 0.001 & 0.02 & 0.008 & 0.01 \\
\hline
\end{tabular}

*values of $\mathrm{P}<0.05$ were considered statistically significant

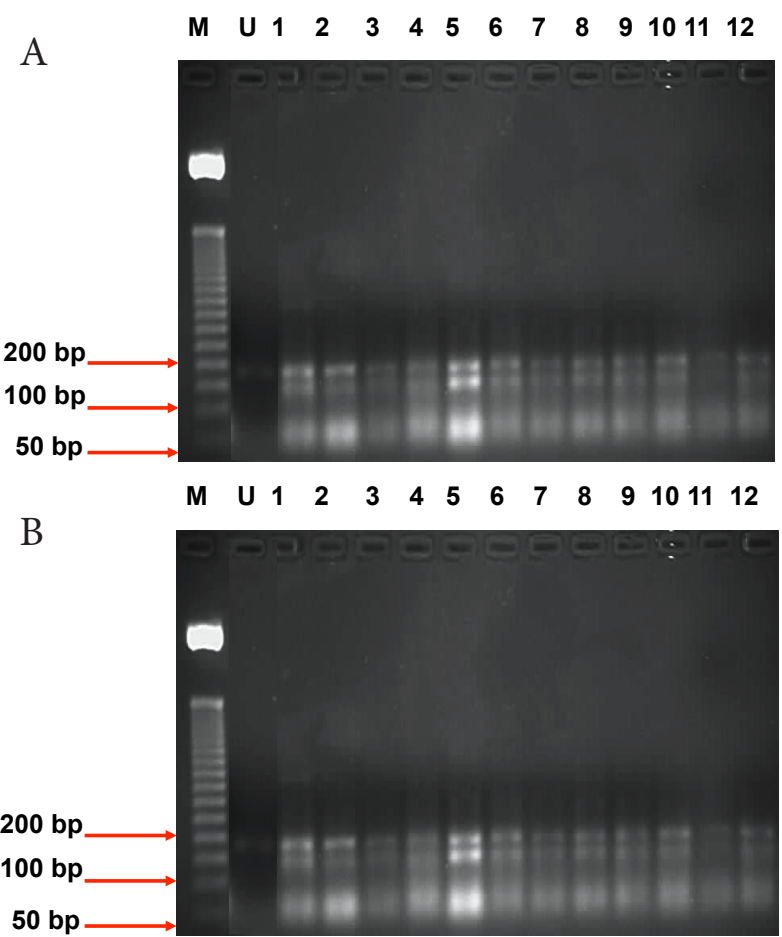

Figure 3. Agarose Gel Electrophoresis Findings. A): GSTO2 PCR-RFLP product. lane $M, 50$ bp DNA ladder lane $\mathrm{U}$,uncut band (185 bp). Lanes 1-12 G/A heterozygous type (185 bp , 122 bp and 63 bp). B): Agarose gel electrophoresis of GSTO2 PCR-RFLP product. lane M ,50 bp DNA ladder. lane $\mathrm{U}$,uncut band (185 bp).lane 1,2. A/A homozygous of wild type (185 bp). Lanes 3-8, G/G homozygous of polymorphic type (122 bp, 63 bp)

for GSTO1 (C/C) \} as compared to C group (Figure 4A). GSTO2: GSTO2 (A/A) was decreased significantly in $\mathrm{N}, \mathrm{A}, \mathrm{CH}, \mathrm{CI}$ and $\mathrm{HCC}$ groups by about $50 \%, 50 \%$, $94.4 \%, 88.9 \%$ and $94.4 \%$ respectively, However, GSTO2 $(\mathrm{A} / \mathrm{G})$ and GSTO2 $(\mathrm{G} / \mathrm{G})$ genotypes were increased significantly by about $105.8 \%, 93.9 \%, 57.5 \%, 57.5 \%$ and $45.4 \%$ respectively, for GSTO2 (A/G)and $(6.4 \%$, $33.2 \%, 326.6 \% 300 \%$ and $353.2 \%$ respectively, for GSTO2 $(\mathrm{G} / \mathrm{G})$ ) as compared to $\mathrm{C}$ group (Figure 4).

HBV DNA titer values: The results showed that the

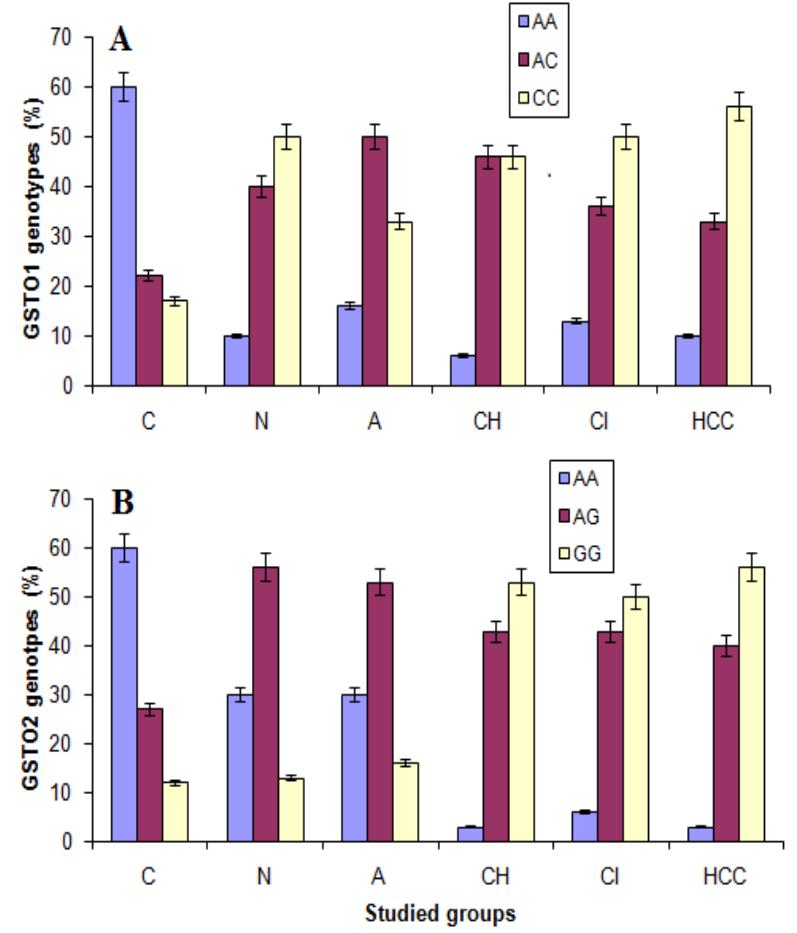

Figure 4. Relationship between Genotype Frequency and Studied Groups: A) GST01; B) GST02

HBV DNA titer values (as mean $\pm \mathrm{SD}$ and $\mathrm{p}$ value $=$ 0.002 ) for $\mathrm{N}, \mathrm{A}, \mathrm{CH}, \mathrm{CI}$ and $\mathrm{HCC}$ groups were $5 \times 10^{3} \pm$ $3.5 \times 10^{3}, 30 \times 10^{8} \pm 12 \times 10^{8}, 60 \times 10^{6} \pm 27 \times 10^{6}, 20 \times 10^{6}$ $\pm 15 \times 10^{6}$ and $7 \times 10^{5} \pm 5.5 \times 10^{5} \mathrm{IU} / \mathrm{ml}$, respectively. IU/ $\mathrm{ml}$ is international unit per $\mathrm{ml}$ which equivalent to five copies per $\mathrm{ml}$. The values of $\mathrm{P}<0.05$ were considered statistically significant

\section{Discussion}

The results showed that there was no significant relationship between different stages of $\mathrm{HBV}$ infection and HBV DNA titer. These results agree with the previous studies (Lindh et al., 2000, Yuen et al., 2004, Shaban et al., 2014 d). In contrast, other studies reported that patients who had increased liver damage had lower viral load (Chu 
et al., 2002, Heo et al., 2003). The current study showed a reduction in GST activities in different HBV groups ( $\mathrm{N}, \mathrm{A}, \mathrm{CH}, \mathrm{CI}$ and $\mathrm{HCC}$ ) as compared to the $\mathrm{C}$ group. This indicates that GST activity was decreased with the development of HBV infection stages and this may be related to inflammation and hepatocytes injury. On the other hand, our previous studies showed that oxidative stress and lipid peroxidation and GSR were increased, while GSH level and activities of GST, SOD and GST were decreased in all different HBV groups (Shaban et al., 2014c). The study also showed that lipid peroxidation which lead to hepatocytes injury was increased with the development of HBV infection stages.

Otherwise, previous studies showed that GSTA1, GSTT1, GSTP1 and GSTM1 polymorphic variants are associated with altered catalytic function of GST (Becket et al., 1997, Shaban et al., 2014 d).

In this study GST activities were within normal ranges in wild GSTO genotypes GSTO1 AA and GSTO2 AA, while they were decreased significantly in mutant GSTO genotypes GSTO1 AC, GSTO CC, GSTO2 AG and GSTO2 GG). These data agree with previous study which showed that GST activities were within the normal range in the genotypes of wild GSTT1/GSM1, GSTP1 Ile/Ile and GSTA1 AA. However GST activities were decreased significantly in the genotypes of null GSTM1, null GSTT1, null GSTM1/GSTT1, GSTP1 Val/ Val, GSTA1 AB and GSTA1 BB (Shaban et al., 2014 d). This indicates that GST activities were decreased in GST mutant genotypes rather than wild types. Therefore, patients who are genetically predisposed to produce a less active and less specific enzyme might be more susceptible to develop HBV-related liver disease. The widespread distribution of GSTO1 suggests that it has important biological functions. It is possible that the glutathione-dependent dehydroascorbate-reductase and thiol-transferase activities of GSTO1 may be generally required for normal cellular process and protection against cellular oxidative stresses (Whitbread et al., 2005). In addition, previous studies reported that GSTO1 may have a role in protection against calcium-induced apoptosis in cells containing ryanodine receptors (Dulhunty et al., 2001). Till now, there are no studies discussing the relationship between the genetic polymorphism of GSTO1 and different stages of HBV infection. However, the current study showed that the frequency of GSTO1 mainly $\mathrm{A} / \mathrm{C}$ and $\mathrm{C} / \mathrm{C}$ genotypes increased in $\mathrm{N}, \mathrm{A}, \mathrm{CH}$, $\mathrm{CI}$ and $\mathrm{HCC}$ as compared to $\mathrm{C}$ group. These results agree with previous study which reported that a significantly higher risk of breast cancer among heterozygous or homozygous carriers of GSTO1*D140, but absent in carriers of GSTO2*D142 (Marahatta et al., 2006). Also, the previous results demonstrated that homozygous carriage of GSTO1*D140 was significantly associated with higher risk, especially for estrogen- receptor-positive breast cancer (Oslen et al., 2008). Several studies have shown that the polymor $\neg$ phism of GSTO2 has a role in the colorectal, gastric and hepatocellular carcinoma (Marahatta et al., 2006, Masoudi et al., 2009 and 2011). It has been reported that there is no associa $\neg$ tion between GSTM1 and GSTT1 polymor $\neg$ phism and acute rejection
Distribution of GST Omega Genes with HBV Infection Stages

of liver transplantion (Azarpira et al., 2010). In addition, augmentation of GG allele can increase the risk of hepatic failure that leads to liver transplantation (Mukherjee et al., 2006). Our previous study demonstrated that there is an elevation in the levels of GSTP1 Val/IIe, GSTP1 Val/Val, null GSTM1, double null GSTM1/GSTT1, GSTA1 AB and GSTA1 BB genotypes with a reduction in the levels of GSTP1 IIe/IIe, wild GSTM1/GSTT1 and GSTA1 AA genotype in $\mathrm{N}, \mathrm{A}, \mathrm{CH}, \mathrm{CI}$ and $\mathrm{HCC}$ as compared to $\mathrm{C}$ group (Shaban et al., $2014 \mathrm{~d}$ ).

The current study showed that GSTO2 A/G and GSTO2 G/G mutant genotypes were increased in N, A, $\mathrm{CH}, \mathrm{CI}$ and $\mathrm{HCC}$ as compared to $\mathrm{C}$ group. This indicates that GSTO2 mutant genotypes were increased with increasing the degree of HBV infection and the patients had mutant GSTO2 genotypes such as $(\mathrm{A} / \mathrm{G}$, and $\mathrm{G} / \mathrm{G})$ were more susceptible for more $\mathrm{HBV}$ disease progression. These results agree with the previous study which reported that there is an association between N142D polymorphism of GSTO2 and susceptibility to several types of cancers. Other studies demonstrated that GSTO2, XRCC1 has an additive effect on the risk of breast cancer (Azarpira et al., 2010, Masoudi et al., 2011). We suggest that the wild type genotype GSTO2 (A/A) can detoxify the active compounds and free radicals better, more rap-idly and efficiently than the mutant genotypes GSTO2 (A/G, G/G), thus, a person with the mutant genotype is more sen $\neg$ sitive to these compounds. People with $\mathrm{A} / \mathrm{G}$ and $\mathrm{G} / \mathrm{G}$ genotype for GSTO2 are more prone to develop hepatic failure.

Otherwise, the present study showed a reduction in the levels of TP and albumin but elevation in total bilirubin level in serum of $\mathrm{N}, \mathrm{A}, \mathrm{CH}, \mathrm{CI}$ and $\mathrm{HCC}$ groups as compared to the $\mathrm{C}$ group. In addition the ALT activities were increased in all studied groups with different degrees but AST activities were increased in all studied groups except HCC group which was decreased as compared to the $\mathrm{C}$ group and this may be due to liver injury. So GSTO genetic polymorphism may be considered as a more accurate biomarker for the diagnosis of $\mathrm{HBV}$ infection stages than transaminases (AST and ALT).

\section{References}

Ada TG, Ada AO, Kunak SC, et al (2013). Association between glutathione S-transferase omega $1 \mathrm{~A} 140 \mathrm{D}$ polymorphism in the Turkish population and susceptibility to non-small cell lung cancer. Arh Hig Rada Toksikol, 64, 247-53.

Azarpira N, Nikeghbalian S, Geramizadeh B (2010). Influence of glutathione S-transferase M1 and T1 polymorphisms with acute rejection in Iranian liver transplant recipients. Mol Biol Rep, 37, 21-25.

Becket GJ, Dyson EH, Chapman BJ, et al (1997). Plasma glutathione S-transferase measurements and liver disease in man. J Clin Biochem Nutr, 2, 1-24.

Board PG, Coggan M, Chelvanayagam G, et al (2000). Identification, characterization and crystal structure of the omega class glutathione transferases. J Biol Chem, 275, 24798-806.

Chisari FV, Ferrari C (1995). Hepatitis B virus immunopathogenesis. Ann Rev of Immunol, 13, 29 - 60.

Chu CJ, Lok ASF (2002). Clinical utility in quantifying serum HBV DNA levels using PCR assay. J hepatol, 36, 549 -51.

Danil S, Pratt MD, Marshal M (1999). Evaluation of the liver: 
laboratory tests. in Schiff's Diseases of the Liver, 8th edn. USA; JB Lippincott Publications, 205, 39.

Dulhunty A, Gage P, Curtis S, et al (2001). Glutathione transferase structural family includes a nuclear chloride channel and a ryanodine receptor calcium release channel modulator. J Biol chem, 276, 3319-23.

Habig WH, Pabst J, Jakoby B (1974). Glutathione S-transferases. The first enzymatic step in mercapturic acid formation. $J$ Biol Chem, 249, 7130- 39.

Hassan MM, Li D, El-Deeb AS (2008). Association between hepatitis B virus and pancreatic cancer. J Clin Oncol, 26, 4557-62.

Heo J, Baik TH, Kim HH, et al (2003). Serum hepatitis B virus (HBV) DNA levels at different stages of clinical course in patients with chronic HBV infection in an endemic area. $J$ Korean Med Sci, 18, 686-90.

Li YJ, Sofia AO, Puting X, et al (2003). Glutathione S-transferase omega-1 modifies age-at-onset of Alzheimer disease and Parkinson disease. Human Mol Gen, 12, 3259-67.

Lindh M, Horal P, Dhillon AP, et al (2000). Hepatitis B virus DNA levels, precore mutations, genotypes and histological activity in chronic hepatitis B. J Vir Hepat, 7, 258-67.

Locarnini SA, Shaw T (2004). Antiviral drug resistance in hepatitis B and C. J Gastroenterol and Hepatol, 9, 322-28.

Marahatta SB, Punyarit P, Bhudisawasdi V, et al (2006). Polymorphism of glutathione S-transferase omega gene and risk of cancer. Canc Lett, 236, 276-81.

Masoudi M, Saadat I, Omidvari SH(2009). Genetic polymorphisms of GSTO2, GSTM1, and GSTT1 and risk of gastric cancer. Mol Biol Rep, 36, 781-84.

Masoudi M, Saadat I, Omidvari S, et al (2011). Association between N142D genetic polymorphism of GSTO2 and susceptibility to colorectal cancer. Mol Biol Rep, 38, 430913.

Miller SA, Dykes DD, Polesky HF (1998) . A simple salting out procedure for extracting DNA from human nucleated cells. Nucl Acid Res, 16, 3.

Mukherjee B, Oreste ES, Linda LP, et al (2006). Glutathione S-transferase omega 1 and omega 2 pharmacogenomics. Am Soc Pharmacol Expert Therap, 34, 1237-46.

Oslen A, Autrup H, Sorensen M , et al (2008). Polymorphisms of glutathione S-transferase A1 and O1 and breast cancer among postmenopausal Danish women. Europ J Canc Prev, 17, $225-29$.

Polimantia R, Piacentinia S, De Angelisa F, et al (2011). Human GST loci as markers of evolution nary forces: GSTO1*E155del and GSTO1*E208K polymorphisms may be under natural selection induced by environmental arsenic. Dis Mark, 31, 231-39.

Pongstaporn W, Pakakasama S (2009). Polymorphism of glutathione S-transferase Omega gene: association with risk of childhood acute lymphoblastic leukemia. J. Canc Res and Clin Oncol, 135, 673 -78.

Pongstaporn W, Pakakasama S, Sanguansin S, et al (2008). Polymorphism of glutathione S-transferase omega gene: association with risk of childhood acute lymphoblastic leukemia. J Cancer Res Clin Oncol, 432, 501-04.

Pongstaporn W, Rochanawutanon M, Wilailak S, et al (2006). Genetic alterations in chromosome 10q24.3 and glutathione S-transferase omega 2 gene polymorphism in ovarian cancer. J Exp Clin Cancer Res, 25, 107-14.

Schmuck EM, Board PG, Whitbread AK, et al(2005). Characterization of the monomethylarsonate reductase and dehydroascorbate reductase activities of omega class glutathione transferase variants: implications for arsenic metabolism and the age-at-onset of Alzheimer's and Parkinson's diseases. Pharmacogen Genom, 15, 493-01.
Shaban NZ, Abdul-Aziz AA (2014a). Effect of Meloxicam on Lipoxygenase Activity in Trachea, Skin, Stomach and Serum of Rabbits (in Vivo and in Vitro). Life Sci J, 11, 48-55.

Shaban NZ, El-Kersh MA, Bader-Eldin MM, et al (2014b). Effect of punica granatum (pomegranate) juice extract on healthy liver and hepatotoxicity induced by diethylnitrosamine and phenobarbital in male Rats. J Med Food, 17, 339-49.

Shaban NZ, El-Kersh MA, El-Rashidy FH, et al (2013). Protective role of Punica granatum (pomegranate) peel and seed oil extracts on diethylnitrosamine and phenobarbitalinduced hepatic injury in male rats. Food Chem, 141, 1587-96.

Shaban NZ, Helmy MH, El-Kersh MA, et al (2003). Effects of Bacillus thuringiensis toxin on hepatic lipid peroxidation and freeradical scavengers in rats given alpha-tocopherol or acetylsalicylate. comparative biochemistry and physiology part C. Toxicol Pharmacol, 135, 405-14.

Shaban NZ, Salem HM, Elsaadany MA, et al (2014c). Alteration in lipid peroxidation and antioxidant in patients with different stages of hepatitis B virus infection in Egypt. Life Sci J, 11, 960-67.

Shaban NZ, Salem HM, Elsaadany MA, et al (2014d). Association between the genetic polymorphism of glutathione $\mathrm{S}$-transferase genes and the different stages of hepatitis B virus infection in Egypt. Life Sci J, 11, 723-30.

Strange RC, Strange MA, Spiteri S, et al (2001). Glutathione-Stransferase family of enzymes. Mutat Res, 482, 21-6.

Wang FS (2003). Current status and prospects of studies on human genetic alleles associated with hepatitis B virus infection. W J Gastroenterol, 9, 641-44.

Whitbread AK, Masoumi A, Tetlow N, et al (2005). Characterization of the omega class of glutathione transferases. Method Enzymol, 401, 78-99.

Whitbread AK, Tetlow N, Eyre HJ, et al (2003). Characterization of the human omega class glutathione transferase genes and associated polymorphisms. Pharmacogen, 13, 131-44.

William W (1997). Effect of $\mathrm{pH}$ and ionic strength on the spectrophotometric assessment of nucleic acid purity. Biotech, 22, 474-81.

Yuen MF, Oi-Lin NI, Fan ST (2004). Significance of HBV DNA levels in liver histology of $\mathrm{HBeAg}$ and anti-HBe positive patients with chronic hepatitis B. Amer J Gastroenterol, 99, 203-27. 